\title{
PENGGUNAAN FACEBOOK OLEH INVESTOR
}

\author{
Peter Garlans Sina \\ Universitas PGRI NTT, Indonesia \\ Email: petersina83@gmail.com
}

\begin{abstract}
Abstrak: Penggunaan Facebook oleh Investor. Tujuan dari penelitian ini adalah memberikan bukti tambahan tentang dampak negatif dari penggunaan facebook sebagai jejaring sosial antara investor dalam membuat keputusan investasi serta bagaimana cara mereduksinya. Hasil menunjukkan bahwa penggunaan facebook mengarahkan pada pembentukan keyakinan yang keliru sehingga bertendensi membuat keputusan investasi yang bias. Pada bagian akhir penelitian ini, dijabarkan cara mereduksinya.
\end{abstract}

Kata Kunci: investasi, jaringan sosial, facebook

\begin{abstract}
The Use of Facebook by Investors. The purpose of this study is to give additional evidence of the negative impacts of the use of Facebook as a social networking between investors in making investment decisions and how to reduce it. The results showed that the use of Facebook leads to the formation of erroneous beliefs that tend to make bias investment decisions. At the end of the study, it was described how to reduce them.
\end{abstract}

Keywords: investment, social network, facebook

\section{PENDAHULUAN}

Firman (2009) sebagaimana dikutip Agustin (2012) menjelaskan bahwa salah satu situs jejaring sosial yang paling fenomenal adalah Facebook. Situs jejaring sosial ini menawarkan kepada anggotanya kemampuan untuk menciptakan webpage pribadi, mengirimkan informasi yang berhubungan dengan diri anggota, serta berinteraksi dengan orang-orang yang tidak mungkin disatukan dalam dunia nyata ke dalam satu media dengan bantuan sambungan internet.

Masih dari sumber yang sama, bukti fenomenal Facebook ini terlihat dari angka pertumbuhan anggota barunya mencapai 250.000 orang per hari, angka monthly visitnya mencapai 1.191.373.339 kali setahun, mengalahkan Google sebagai situs yang paling sering dikunjungi tahun 2008 dan 2009, serta menjadi situs dengan waktu stay visitor terlama di dunia, yakni 13 miliar menit.

Saat ini penggunaan FB di Indonesia sudah menjadi rutinitas sehari-hari, mulai dari pelajar, mahasiswa, guru, dosen, pengusaha, pengacara, politisi, artis, tokohtokoh dunia dan lain-lain, dan dari berbagai kelas dan golongan karena masalah penggunaan internet sudah bukan barang yang mahal. Hal ini disebabkan hanya dengan beberapa ribu rupiah saja sudah bisa menjelajah ke dunia maya di warnet-warnet pinggir jalan sehingga penggunaan FB merupakan hal yang biasa seperti penggunaan internet pada umumnya (Juditha, 2011). 
Terkait bidang keuangan, Baker dan Nofsinger (2002) menambahkan bahwa keberadaan internet sebagai salah satu alat jejaring sosial bertendensi mempengaruhi pasar saham. Keberadaan tersebut memperkuat interaksi sosial antara investor yang mana akan berefek pada keputusan keuangan. Lanjut bahwa hal itu dimungkinkan disebabkan internet memberikan kemudahan dalam memperoleh informasi dan bergabung dengan investor lainnya yang biasanya disebut sebagai online investor.

Tidak jauh berbeda, Turri, Maniam, dan Earl (2007) juga menjelaskan bahwa dengan meningkatnya penggunaan internet secara global menyebabkan berbagai kemudahan untuk menawarkan berbagai produk dan jasa pada world wide web. Selain itu, keberadaan internet juga memberikan kemudahan bagi investor untuk melakukan transaksi, entah itu investor perorangan, investor institusi serta broker.

Choi, Laibson, dan Metrick (2000) menemukan bahwa keberadaan internet memberikan investor kemudahan yang luar biasa karena dapat melakukan transaksi dengan lebih mudah. Lanjut bahwa dikarenakan kemudahan dan kelebihan pada aspek waktu untuk melakukan transaksi menyebabkan peningkatan dua kali lebih besar untuk melakukan transaksi. Investor dalam melakukan transaksi untuk pensiun akan melakukannya berulang kali sehingga volatisitas saham menjadi meningkat.

Saat membandingkan kinerja investor yang melakukan online trading dan yang tidak, Oh, Parwada, dan Walter (2007) menemukan bahwa investor di Korea yang semakin familiar dengan pasar saham dan melakukan transaksi saham secara online memiliki kinerja yang buruk dibandingkan yang tidak atau relatif kecil melakukan transaksi online. Temuan ini membuktikan bahwa melakukan online trading bertendensi lebih banyak melakukan transaksi sehingga mengalami bias pada keputusan investasi. Sementara itu, Heimer dan Simon (2012) menemukan bahwa kehadiran facebook sebagai jejaring sosial mempengaruhi investor untuk melakukan transaksi saham sehingga adanya facebook sebagai salah satu media sosial akan menentukan perolehan return.

Berpijak pada berbagai temuan sebelumnya, tampak bahwa internet khususnya facebook sebagai jaringan sosial memberikan efek negatif pada investor sehingga berpeluang mengalami penyimpangan return. Hal ini menyebabkan investor berpeluang mengalami kegagalan mencapai kebebasan keuangan. Apabila diperas maka eksistensi facebook sebagai salah satu jaringan sosial berdampak positif negatif atau merugikan investor yang mana menjadi masalah penelitian ini. Oleh sebab itu tujuan dari penelitian ini yaitu memberikan bukti tambahan tentang dampak negatif dari penggunaan facebook serta cara mereduksinya yang mana akan menggunakan teori-teori serta hasil penelitian yang relevan untuk membedahnya.

\section{PEMBAHASAN}

Sesuai dengan masalah dan tujuan penelitian ini, selanjutnya akan dijabarkan beberapa teori dan hasil penelitian untuk membedahnya. Menurut Zurkowski dalam Puri dan Sainttyauw (2011), informasi 
merupakan sebuah entitas yang berpotensi untuk menjadi sebuah kekuatan sekaligus sumber kebingungan bagi banyak orang. Setiap hari kita ditantang untuk berhadapan dengan informasi yang melimpah ruah dan melaju dengan kencang, dalam berbagai format yang terhitung pula jumlahnya.

Keterampilan dasar dalam melek informasi yang tidak lain adalah kemampuan untuk mengakses, mengevaluasi dan menggunakan informasi dari berbagai sumber secara efektif, menjadi sebuah keahlian yang teramat penting dan harus dikuasai oleh semua pihak baik pustakawan maupun penggunaan. Lanjut, masyarakat yang mampu dan terampil dalam menggunakan sumber informasi dalam bidang pekerjaan mereka dapat dikatakan sebagai masyarakat yang melek informasi. Orang telah mempelajari dengan terampil bagaimana caranya menggunakan sejumlah alat informasi untuk memecahkan masalah mereka.

Salah satu alat jalinan informasi adalah facebook yang mana merupakan merupakan salah satu dari bentuk jaringan sosial. Menurut Dirgayuza (2008) yang disadur oleh Juditha (2011), situs jejaring sosial yang dalam bahasa Inggris disebut social network sites merupakan sebuah web berbasis pelayanan yang memungkinkan penggunanya untuk membuat profil, melihat daftar pengguna yang tersedia, serta mengundang atau menerima teman untuk bergabung dalam situs tersebut. Tampilan dasar situs jejaring sosial ini menampilkan halaman profil pengguna, yang di dalamnya terdiri dari identitas diri dan foto pengguna. Kemunculan situs jejaring sosial ini diawali dari adanya inisiatif untuk menghubungkan orang-orang dari seluruh belahan dunia.

Selanjutnya Sharpe, Alexander, dan Bailey (1999) menjelaskan bahwa investasi merupakan mengorbankan sejumlah uang pada masa sekarang untuk sejumlah uang di masa depan. Dalam hal ini aspek waktu dan risiko menjadi sentral dalam investasi karena mengorbankan uang sekarang dan memperoleh kembali di masa depan sehingga semakin lama durasi waktu maka semakin tidak pasti imbal hasil yang akan diperoleh. Oleh sebab adanya ketidakpastian dalam memperoleh return maka keputusan investasi perlu dibuat berdasarkan analisis yang mendalam dan komprehensif.

Shefrin (2007) memperkuat bahwa analisis yang mendalam dibutuhkan untuk membuat keputusan investasi oleh investor. Dalam proses membuat keputusan investasi itulah seringkali investor mengalami bias sehingga meningkatkan penyimpangan imbal hasil. Hasil penelitian Heimer dan Simon (2012) menemukan bahwa facebook bukan hanya sebagai alat saling menghubungkan antara individu yang mana facebook sebagai salah satu media sosial melainkan juga mempengaruhi investor membuat keputusan investasi. Hasil interaksi antara investor berpeluang mempengaruhi persepsi investor untuk melakukan transaksi saham.

\section{Dampak Negatif Penggunaan Facebook}

Dalam upaya membuat keputusan investasi yang profitabel, informasi menjadi input utama bagi investor untuk proses membuat keputusan investasi (Hirschey \& Nofsinger, 2008). Dalam hal ini, pengelolaan informasi secara tepat dapat mereduksi peluang membuat keputusan yang bias namun bukan 
meniadakan suatu risiko. Tidak meniadakan karena adanya risiko sistematis serta peluang mengalami bias pada saat membuat keputusan keuangan. Lanjut bahwa disebabkan adanya ketidakpastian itulah maka investor yang tidak dapat mengontrol diri akan cenderung mengalami penyimpangan imbal hasil.

Sementara itu, Barber dan Odean (2001) menjelaskan bahwa kehadiran internet sebagai salah satu media interaksi menyebabkan pengiriman dan perolehan informasi kepada investor menjadi cepat dan menjadi dasar bagi investor untuk bertindak. Lanjut bahwa kehadiran internet sebagai salah satu jejaring sosial memberikan keuntungan bagi berbagai perusahaan investasi, entah itu perusahaan kecil maupun besar karena investor bertendensi melakukan transaksi online.

Alhasil investor memiliki kemudahan dalam transaksi sebelum seperti dekade yang lalu. Namun kemudahan memperoleh informasi dan memiliki lebih banyak pilihan juga memiliki kekurangan juga yaitu lingkungan yang tidak pasti. Ketidakpastian terhadap pilihan informasi yang relevan sehingga membutuhkan kemampuan kognitif untuk mengolah sebegitu banyaknya informasi. Terutama bagi investor pemula yang belum memiliki pengalaman dalam transaksi saham maka berbagai kemudahan tersebut dapat menyebabkan melakukan transaksi yang berlebihan atau pun mengalami analisis yang keliru.

Pada saat melakukan analisis yang keliru maka peluang mengalami imbal hasil pun dapat terjadi. Dalam hal ini, apakah keputusan investasi yang dibuat itu tepat ataukah tidak namun melalui proses pembuatan keputusan investasi yang diusahakan tepat akan meningkatkan peluang untuk menghasilkan keputusan investasi yang tepat dan begitu juga sebaliknya.

Lebih jauh kedua peneliti menjelaskan bahwa kemudahan memperoleh informasi dapat mengarahkan investor membentuk keyakinan yang keliru bahwa dengan memperoleh banyak informasi akan menjamin keputusan investasi yang dibuat adalah tepat. Dengan kata lain, memperoleh informasi yang banyak atas suatu saham berpeluang mengarahkan investor untuk meyakini bahwa pasti akan memperoleh return investasi. Dalam hal ini, kehadiran internet sebagai salah satu jejaring investor memperoleh informasi belum tentu diringi dengan kemampuan investor mengolah informasi atau pun pengalaman yang rasional untuk membuat keputusan investasi.

Tidak jauh berbeda, Barber dan Odean (2002) menjelaskan bahwa melakukan perdagangan online memberikan keadilan dalam berinvestasi karena investor dapat saja memperoleh akses dalam melakukan transaksi saham. Namun hal itu sekali lagi perlu memikirkan konsekuensi logis atas kemampuan mengolah informasi sehingga tidak serta meyakini bahwa pasti mampu mengalahkan return pasar. Dalam hal ini, perilaku investor seperti dapat membuat harga saham meningkat tajam tanpa adanya alasan yang masuk akal atau pun mengalami penurunan tanpa disertai alasan yang logis.

Hasrat untuk memperoleh kekayaan secara langsung dalam jangka waktu singkat mendorong perilaku investor memanfaatkan berbagai informasi yang mana tanpa 
dipikirkan dengan cermat. Pada saat harga saham mengalami peningkatan dan mengalami penurunan karena begitu banyaknya penawaran maka akan banyak investor yang akan mengalami kerugian karena membeli dengan harga tinggi dan menjual di dengan harga rendah. Oleh sebab itu, ketelitian dan kecermatan membuat keputusan investasi perlu dilakukan dengan baik oleh investor.

Investor yang berorientasi jangka pendek akan bertendensi melakukan transaksi saham yang banyak sehingga walaupun harga saham mengalami peningkatan dan penurunan namun hal itu belum tentu investor memperoleh keuntungan dan hal inilah yang seringkali dilupakan oleh investor. Posisi investor dapat lebih mudah mengambil posisi bertahan atau keluar dari pasar dan tanpa disadari mendorong fluktuasi harga saham dan inilah mengapa suatu pasar saham dapat memiliki dinamika yang intensitasnya tinggi. Namun sekali lagi bahwa kemudahan itu tidak memastikan investor memperoleh return karena adanya biaya transaksi.

Heimer dan Simon (2012) menspesifikkan lagi dengan menggunakan pendekatan model yang dibangun oleh Hirshleifer (2010) bahwa pengaruh media sosial dalam perilaku investor akan mengarahkan pada arbitrase sehingga semakin banyak investor yang melakukan transaksi. Pola komunikasi antara investor terutama investor berorientasi jangka pendek akan mengalami peningkatan. Apalagi ditambah baru saja memperoleh keuntungan maka akan semakin mendorong hasrat untuk bertransaksi lebih banyak lagi dan mempengaruhi persepsi investor lainnya untuk melakukan hal yang sama.
Lebih jauh kedua peneliti menjelaskan bahwa facebook sebagai jaringan sosial menyebabkan investor dengan begitu mudahnya saling sharing kepada sesama investor. Selain itu, kehadiran facebook juga dapat digunakan untuk melakukan konsultasi ide investasi dengan pakar investasi yang mana hasilnya adalah keputusan investasi. Jadi dalam hal ini facebook juga merupakan salah satu alat penyaluran informasi terkait suatu saham.

Lanjut bahwa facebook sebagai media sosial saling interaksi antara investor juga menyediakan kemudahan dalam bentuk aspek efisiensi dalam perolehan informasi karena dapat dilakukan lebih mudah dibandingkan perlu menghubungi broker melalui telepon. Kemudahan ini memberikan daya tarik bagi investor untuk menggunakan facebook sebagai penyedia informasi yang efisien namun belum tentu memberikan efektivitas. Karena berbagai ide hasil interaksi sosial antara investor belum tentu tepat sehingga berpeluang mengalami bias.

Saat keputusan investasi mengalami bias maka investor akan mengalami kerugian. Oleh sebab itu mendukung penjelasannya Barber dan Odean (2001) bahwa walaupun informasi mudah diperoleh namun masih membutuhkan pengolahan lebih lanjut untuk menghasilkan keputusan investasi yang tepat. Senada, Baker dan Nofsinger (2002) juga mengungkapkan penjelasan serupa bahwa kemudahan memperoleh informasi atau pun kemudahan berinteraksi antara investor tidak menjamin seorang investor memperoleh return. Apabila disinergiskan dan diperas maka investor yang menggunakan facebook dapat saja mengalami overconfidence yang mana hal ini 
akan mempersulit investor untuk memperoleh return karena membuat keputusan investasi yang bias.

Lanjut bahwa penggunaan facebook oleh investor dapat memicu suatu perilaku kawanan (herd behavior) karena tanpa disadari interaksi antara investor di facebook mempenagruhi persepsi investor untuk melakukan transaksi menjual, membeli atau menahan saham yang dimiliki. Namun hasil penelitian terkait penggunaan online trading menunjukkan bahwa investor bertendensi sangat aktif melakukan perdagangan sehingga tidak mempertimbangkan biaya transaksi.

Dalam hal ini, dapat saja investor membuat keputusan investasi yang tepat dan memperoleh return namun karena melakukan transaksi berulang kali maka return yang diperoleh tereduksi oleh biaya transaksi. Kondisi lebih buruk lagi apabila investor membuat keputusan investasi yang keliru dan berulang kali melakukan transaksi maka investor akan semakin banyak kehilangan modal. Biasanya yang melakukan transaksi dengan intensitas tinggi adalah investor jangka pendek yang mana dalam melakukan transaksi dalam sehari dapat berulang kali.

Penggunaan facebook oleh investor dapat mengarahkan pada pembentukan yang keliru bahwa menyangka opini yang beredar di facebook sebagai informasi yang berharga. Memang kehadiran facebook membuat investor saling menyampaika ide dan gagasan namun hal itu tidak memberikan kepastian akan memperoleh return karena dapat menyesatkan investor membenarkan sesuai opini dari investor lainnya sebagai suatu fakta dan hal ini akan memberikan suatu respon yang berbeda. Apabila opini yang diperoleh adalah suatu kebenaran maka sudah pasti semua investor yang menggunakan facebook sebagai media sosial akan memperoleh return namun pada kenyataannya tidaklah demikian karena belum tentu opini hasil interaksi antara investor di facebook adalah tepat (Wolfram, 2010).

Dalam beberapa hal kehadiran facebook memberikan kemudahan bagi investor sebagai jaringan sosial untuk berbagai ide investasi dan hasil analisis. Namun dibalik kemudahan itu juga terdapat suatu hal yang perlu di pikirkan dengan tepat yaitu tentang suasana hati atau mood. Facebook sebagai salah satu jejaring sosial memberikan akses untuk saling terhubung dengan investor lainnya, hanya saja apabila terjadi sesuatu yang mendorong investor untuk mengalami bad mood maka tanpa disadari akan dishare kepada investor lainnya sehingga mempengaruhi mood investor lainnya. Atau pun sedang mengalami good mood maka hal itu akan mempengaruhi persepsi investor lainnya untuk melakukan transaksi saham yang biasanya berlebihan.

Dalam kondisi mood investor yang berubah-ubah maka harga saham pun akan mengalami perubahan karena adanya dorongan permintaan pada saat good mood atau pun penawaran pada saat bad mood. Ketika terjadi seperti itu maka keputusan investasi yang dibuat investor pun berpeluang mengalami bias sehingga meningkatkan peluang memperoleh penyimpangan imbal hasil investasi (Mao, Counts \& Bollen, 2011). Sementara itu, Gray menjelaskan bahwa penggunaan facebook sebagai media sosial merupakan suatu 
tindakan yang rasional oleh investor karena dalam proses interaksi atau komunikasi melalui facebook maka investor cenderung membangun informasi yang bersifat privat.

Dalam proses interaksi tersebut, investor cenderung membagikan pengalaman seperti kesalahan membuat keputusan investasi pada investor lainnya. Atau pun pengalaman memperoleh return tanpa analisis yang mendalam. Namun hasil kajian ini masih perlu disesuaikan juga dengan penjelasannya Baker dan Nofsinger (2002) bahwa interaksi melalui media sosial perlu dipijak pada bagaimana mengolah informasi sehingga walaupun adanya saling sharing pengalaman antara investor namun belum tentu memastikan terbentuknya persepsi yang benar untuk membuat keputusan investasi yang tepat. Dengan demikian, penggunaan facebook oleh investor sebagai media sosial atau media interaksi sosial tidak menjamin dibuatnya keputusan investasi yang tepat sasaran disebabkan untuk meningkatkan peluang membuat keputusan investasi yang tepat membutuhkan kecerdasan investor mengolah informasi dan mengendalikan diri pada saat berinvestasi di pasar saham.

\section{Mereduksi Dampak Negatif Penggunaan Facebook}

Setiap keputusan investasi merupakan suatu hal yang kompleks menimbang perlu mempertimbangkan berbagai informasi. Dalam hal ini, kemampuan mengolah informasi menjadi kunci keberhasilan investor untuk membuat keputusan investasi (Hirschey \& Nofsinger, 2008). Pada saat investor menerima informasi dari berbagai termasuk facebook sebagai jaringan sosial atau media sosial maka perlu mengolahnya terlebih dahulu sebelum memutuskan suatu keputusan transaksi sehingga tidak serta meyakini bahwa informasi yang diterima hasil interaksi dengan investor lainnya menggunakan facebook langsung dijadikan kesimpulan final.

Terkait dengan penjelasan sebelumnya, Baron (2008) memperkuat bahwa kurang tingginya kemampuan berpikir akan menyebabkan kesalahan dalam pembuatan kesimpulan. Karena seseorang yang berkemampuan tinggi dalam berpikir cenderung mampu mengombinasi kemungkinan dan bukti untuk membuat kesimpulan yang tepat karena interaksi antara kedua hal tersebut akan menentukan tepat tidaknya kemampuan berpikir. Kemungkinan dapat diartikan sebagai jawaban yang mungkin terhadap pertanyaan yang memicu seseorang berpikir, sedangkan bukti dapat diartikan sebagai hal yang mendasari logis tidaknya suatu kemungkinan.

Tanpa dipahami secara tepat akan dua komponen utama tersebut maka hanya akan mengakibatkan bias dalam pembuatan keputusan. Nalarnya yaitu membuat keputusan berdasarkan kesesuaian dengan gambaran mental yang tersimpan dalam benak, maka seseorang cenderung mengabaikan kemungkinan. Dengan mengabaikan kemungkinan maka akan mengalami kesulitan untuk mendapatkan bukti. Tanpa perolehan bukti maka akan mengakibatkan kesalahan dalam pembuatan keputusan.

Sementara itu Graham yang mempopulerkan strategi investasi berbasis value dan diadopsi dengan benar oleh Warren Buffet menegaskan bahwa dalam 
melakukan investasi saham maka dibutuhkan kecerdasan emosi sebagai pembentuk keputusan transaksi untuk disinergiskan dengan kecerdasan inteligensi. Kombinasi keduanya akan memberikan investor keuntungan pada saat membuat keputusan investasi karena investor akan berpikir dua kali sebelum membuat keputusan investasi (think twice).

Mengacu pada ulasan-ulasan sebelumnya dapat diperas bahwa cara mereduksi bias pada saat menggunakan facebook sebagai jaringan sosial antara investor adalah pertama perlu meningkatkan kemampuan kognitif sehingga pada saat menerima informasi, opini, dan ide dari investor lainnya tidak langsung meyakini sebagai sebuat kebenaran melainkan dipikirkan dengan cermat terlebih dahulu sebelum memutuskan pilihan investasi. Kedua adalah meningkatkan kecerdasan emosi sehingga meningkatkan kemampuan mengontrol diri pada saat membuat keputusan investasi.

\section{SIMPULAN}

Secara keseluruhan, penggunaan facebook sebagai jaringan sosial relatif mempengaruhi keputusan transaksi investor sehingga mempengaruhi harga saham secara keseluruhan pada suatu pasar saham. Pola komunikasi menggunakan facebook bertendensi mengarahkan investor pada pembentukan persepsi investor sehingga berpeluang mengalami bias pada saat membentuk keputusan investasi. Namun efek negatif dari penggunaan facebook sebagai media sosial antara investor dapat direduksi menggunakan dua cara yaitu meningkatkan kemampuan kognitif untuk mengolah informasi serta meningkatkan kecerdasan emosi untuk meningkatkan pengendalian diri.

\section{DAFTAR PUSTAKA}

Agustin, H. (2012). Pergeseran Perilaku Penggunaan Fitur-Fitur Facebook: Faktor Pemicu, Dampak, Dan Solusi. Seminar Nasional Aplikasi Teknologi Informasi 2012 (SNATI 2012).

Barber, B, M. \& Odean, T. (2001). The Internet and the Investor. Journal of Economic Perspectives, 15(1), 41-54.

Barber, B, M. \& Odean, T. (2002). Online Investor: Do They Slow Die First?. The Review Financial Studies Special, 15(2), 455-487.

Baker, K. H. \& Nofsinger, R. J. (2002). Psychological biases of investors. Financial services review, 11, 97-116.

Baron, J. (2008). Thinking and deciding. Cambridge University Press.

Graham, B. (2008). The Intelligent Investor, Jakarta: Serambi.

Choi, J, J. Laibson, D. \& Metrick, A. (2000). Does The Internet Increase Trading? Evidence From investor Behavior In 401 (k) Plans. Working Paper 7878 http://www.nber.org/papers/w7878

Heimer, R, Z. \& Simon, D. (2012). Facebook Finance: How Social Interaction Propagates Active Investing. Brandeis University, International Business School

Gray, W, R. Facebook for Finance: Why do Investors Share Ideas via Their Social Networks?. Electronic copy available at: http://ssrn.com/abstract $=1304271$

Hirschey, M. \& Nofsinger R. J. (2008). Invesment; Analysis and behavioral. New York: McGraw-Hill/Irwin.

Juditha, C. (2011). Hubungan Penggunaan Situs Jejaring Sosial Facebook Terhadap 
Perilaku Remaja Di Kota Makassar. Jurnal Penelitian IPTEKKOM, 13(1).

Mao, H. C, S. \& Bollen, J. (2011). Predicting Financial Markets: Comparing Survey, News, Twitter and Search Engine Data. arXiv:1112.1051v1 [q-fin.ST] 5 Dec 2011.

Oh, N, Y. Parwada, J, T. \& Walter, T, S. (2007). Investors' trading behavior and performance: Online versus non-online equity trading in Korea. Pacific-Basin Finance Journal, 16, 26-43.

Puri, C, T. S. \& Sainttyauw, A, A, C, Z, J. (2011). Literasi Informasi Kemampuan Ber-
Literasi Informasi Dalam Era Informasi. http://web.unair.ac.id

Sharpe, W, F. Gordon, J. \&, Bailey, J, V. (1999). Investasi. Jakarta: Prehallindo

Shefrin , H. (2007). Behavioral corporate finance: decision that create value. New York: McGraw-Hill/Irwin

Turri, A. Maniam, B. \& Earl, R. (2007). Effects of Online Trading On The Investment Community. ASBBS E-Journal, 3(1).

Wolfram, S, M. (2010). Modelling the Stock Market using Twitter. Thesis. Master of Science Artificial Intelligence School of Informatics University of Edinburgh. 